\title{
负载型 $\mathrm{V}_{2} \mathrm{O}_{5} / \mathrm{TiO}_{2}$ 催化剂表面分散状态和性质对 氨选择性催化还原 NO 性能的影响
}

\author{
唐富顺 ${ }^{1,2}$, 庄 柯 $^{1}$ ，杨 芳 $^{1}$ ，杨利利 ${ }^{1}$ ，许波连 ${ }^{1}$ ，邱金恒 ${ }^{1}$ ，范以宁 ${ }^{1, *}$ \\ 1南京大学化学化工学院, 介观化学教育部重点实验室, 江苏省纳米技术重点实验室, 江苏南京 210093 \\ ${ }^{2}$ 桂林理工大学化学与生物工程学院, “应用电化学新技术”广西高校重点实验室, 广西桂林 541004
}

摘要: 采用多种物理化学手段研究了不同负载量 $\mathrm{V}_{2} \mathrm{O}_{5} / \mathrm{TiO}_{2}$ 催化剂的 $\mathrm{VO}_{x}$ 物种分散状态、表面酸性、可还原性及其选择性催

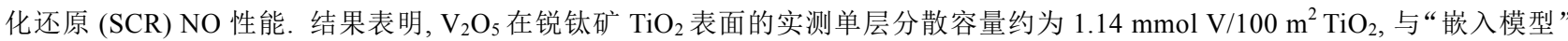
的估算值相符, 表明分散态的钒离子应键合在 $\mathrm{TiO}_{2}$ 表面的八面体空位上. 随着 $\mathrm{V}_{2} \mathrm{O}_{5}$ 负载量的增加, $\mathrm{V}_{2} \mathrm{O}_{5} / \mathrm{TiO}_{2}$ 催化剂上 $\mathrm{NO}$ 转 化频率 (TOF) 先急剧增加, 至 $0.70 \mathrm{mmol} \mathrm{V} / 100 \mathrm{~m}^{2} \mathrm{TiO}_{2}$ (略超过分散容量的一半) 时达到极大 (约 $8.3 \times 10^{-3} \mathrm{~s}^{-1}$ ), 然后又急剧下 降; 同时, 孤立 $\mathrm{VO}_{x}$ 物种可能倾向于分散在相邻的八面体空位上, 且通过 $\mathrm{V}-\mathrm{O}-\mathrm{V}$ 化学键相连形成聚合的 $\mathrm{VO}_{x}$ 物种, $\mathrm{V}-\mathrm{O}-\mathrm{V}$ 键 所占比例增加而 V-O-Ti 键所占比例减小, 催化剂表面单位钒离子的 Brönsted 酸中心量增加, 故催化剂的 TOF 急剧增加. 随 着负载量进一步增加, 虽然催化剂表面单位钒离子的 Brönsted 酸中心量仍缓慢增加, 但 V-O-Ti 键所占比例减少, 导致钒离子 的可还原性下降, 另外, 分散容量以上时晶相 $\mathrm{V}_{2} \mathrm{O}_{5}$ 的形成也导致钒离子表面利用率下降, 从而导致催化剂的 TOF 下降. 桥式 Brönsted 酸位 $(\mathrm{V}-\mathrm{O}(\mathrm{H})-\mathrm{V})$ 也是 $\mathrm{SCR}$ 反应活性中心之一, 不同负载量 $\mathrm{V}_{2} \mathrm{O}_{5} / \mathrm{TiO}_{2}$ 催化剂上 $\mathrm{SCR}$ 活性与表面 $\mathrm{VO}_{x}$ 物种的分散状 态、表面酸性和钒离子可还原性密切相关.

关键词：钒氧物种；分散状态；选择性催化还原；B 酸位；可还原性；氮氧化物

中图分类号: O643 文献标识码: A

收稿日期: 2011-12-21. 接受日期: 2012-01-19.

*通讯联系人. 传真: (025)83317761; 电子信箱: ynfan@nju.edu.cn

基金来源：江苏省扬州市工业科技攻关项目 (YZ2010024); 广西科学研究与技术开发计划项目 (桂科攻 11107021-3-1); 广西教 育厅科研项目 (201010LX186); 桂林理工大学博士基金项目(002401003321).

本文的英文电子版(国际版)由Elsevier出版社在ScienceDirect上出版(http://www.sciencedirect.com/science/journal/18722067).

\section{Effect of Dispersion State and Surface Properties of Supported Vanadia on the Activity of $\mathrm{V}_{2} \mathrm{O}_{5} / \mathrm{TiO}_{2}$ Catalysts for the Selective Catalytic Reduction of $\mathrm{NO}$ by $\mathrm{NH}_{3}$}

\author{
TANG Fushun ${ }^{1,2}$, ZHUANG Ke ${ }^{1}$, YANG Fang ${ }^{1}$, YANG Lili ${ }^{1}$, XU Bolian ${ }^{1}$, QIU Jinheng ${ }^{1}$, FAN Yining ${ }^{1, *}$ \\ ${ }^{1}$ Key Laboratory of Mesoscopic Chemistry of Ministry of Education, Jiangsu Provincial Key Laboratory of Nanotechnology, School of \\ Chemistry and Chemical Engineering, Nanjing University, Nanjing 210093, Jiangsu, China \\ ${ }^{2}$ College of Chemistry and Bioengineering, Guilin University of Technology, Guilin 541004 Guangxi, China
}

\begin{abstract}
The effect of the dispersion state and surface properties of supported vanadia on the selective catalytic reduction (SCR) activity of $\mathrm{NO}$ over $\mathrm{V}_{2} \mathrm{O}_{5} / \mathrm{TiO}_{2}$ catalysts was studied by various experimental techniques. The experimental monolayer dispersion capacity of $\mathrm{V}_{2} \mathrm{O}_{5}$ on anatase $\left(6.86 \mathrm{VO}_{x} / \mathrm{nm}^{2}\right)$ measured by XRD was almost the same as the concentration of surface vacant sites of anatase estimated by the incorporation model, and it was suggested that isolated vanadia species tend to be dispersed on adjacent octahedral vacant sites. An increase of the NO turnover frequency (TOF) at $300{ }^{\circ} \mathrm{C}$ to a maximum $\left(8.3 \times 10^{-3} \mathrm{~s}^{-1}\right)$ at a coverage near half a monolayer was related to the increase of the amount of weak acid sites (Brönsted acid site on each vanadium ion). The TOF decreased rapidly at high $\mathrm{VO}_{x}$ coverages because of a decrease of the reducibility of vanadia species and a decrease of the ratio of exposed vanadia species on the surface. The Brönsted acid sites on bridging $\mathrm{V}-\mathrm{O}(\mathrm{H})-\mathrm{V}$ and terminal $\mathrm{V}-\mathrm{OH}$ of polymeric vanadia species were all active sites in the SCR reaction. The SCR activity of the $\mathrm{V}_{2} \mathrm{O}_{5} / \mathrm{TiO}_{2}$ catalysts was related to the dispersion state, acidity, and reducibility of the vanadia species.
\end{abstract}


Key words: vanadia species; dispersion state; selective catalytic reduction; Brönsted acid site; reducibility; nitrogen oxide

Received 21 December 2011. Accepted 19 January 2012.

*Corresponding author. Fax: +86-25-83317761; E-mail: ynfan@nju.edu.cn

This work was financially supported by the Key Science \& Technology Specific Projects of Yangzhou, Jiangsu Province of China (YZ2010024), the Key Science \& Technology Specific Projects of Guangxi Province of China (11107021-3-1), the Scientific Research Project of Guangxi Education Department (201010LX186), and the Doctoral Foundation of Guilin University of Technology (002401003321).

English edition available online at Elsevier ScienceDirect (http://www.sciencedirect.com/science/journal/18722067).

Supported $\mathrm{V}_{2} \mathrm{O}_{5} / \mathrm{TiO}_{2}$ catalysts have attracted attention because of their unique catalytic properties in the selective catalytic reduction (SCR) of $\mathrm{NO}_{x}$ by $\mathrm{NH}_{3}$. They have high activity, thermal stability, and resistance to poisoning by $\mathrm{SO}_{2}$, and attention have been paid to both their activity and characterization [1-3]. It has been well established that in the sub-monolayer region, vanadia was present on titania as monomeric and polymeric vanadia species, and that the distribution of these species depends on the $\mathrm{VO}_{x}$ coverage [2-7]. At low $\mathrm{VO}_{x}$ coverage in the sub-monolayer region, the catalytic activity of these catalysts depended on the vanadia loading [7-14]. Baiker et al. [8] carried out kinetic measurements at $150{ }^{\circ} \mathrm{C}$ and showed that the NO turnover frequencies (TOF) increased by more than an order of magnitude when the vanadia loading was increased from 1.8 to $3.0 \mu \mathrm{mol} \mathrm{V}^{5+} / \mathrm{m}^{2}$. When the vanadia loading was increased further, the TOF declined, probably due to an increase in bulk $\mathrm{V}^{5+}$ species. Went et al. [7] found that the NO TOF at $227{ }^{\circ} \mathrm{C}$ increased substantially with increasing vanadia loading, and reached a maximum in the range of $4 \%-8 \% \mathrm{~V}_{2} \mathrm{O}_{5}$ as the fraction of polymeric vanadia species reached a maximum at $6 \%\left(15.2 \mu \mathrm{mol} \mathrm{V} \mathrm{V}^{5+} / \mathrm{m}^{2}\right)$. Then the TOF declined as crystallites of $\mathrm{V}_{2} \mathrm{O}_{5}$ were formed at the expense of the polymeric species, suggesting that the polymeric species were more active than the monomeric species. Lietti et al. [9] found that the TOF measured at $227^{\circ} \mathrm{C}$ under steady state conditions over high loading vanadia catalysts was six times higher than that of low loading vanadia catalysts, which was due to their higher amounts of polymeric vanadia species. The increase of NO TOF with increasing $\mathrm{VO}_{x}$ coverage has been attributed to a higher specific activity of the polymeric vanadia species [7] and to the accompanying increase in Brönsted acid sites with $\mathrm{VO}_{x}$ surface coverage [10].

However, Amiridis et al. [15] found that when the SCR reaction was carried out at the high temperatures frequently used for commercial SCR applications and/or at the lower $\mathrm{NO}$ concentrations encountered in a typical flue gas, the NO TOF at $350{ }^{\circ} \mathrm{C}$ first increased with increasing $\mathrm{VO}_{x}$ surface coverage, reached a maximum at a coverage corresponding to approximately half a monolayer, and then decreased rapidly at higher coverage. They argued that the subsequent decrease of TOF at coverages between half and one monolayer can be attributed to the loss of the strong acid sites of the $\mathrm{TiO}_{2}$ support at high $\mathrm{VO}_{x}$ surface coverage. Although there are a number of studies dealing with the SCR activity of $\mathrm{V}_{2} \mathrm{O}_{5} / \mathrm{TiO}_{2}$ catalysts with different $\mathrm{VO}_{x}$ coverages, there is still a debate about the relationship between surface properties and SCR activity. In this work, the nature of vanadia species supported on anatase with different loadings was explored by X-ray diffraction (XRD), infrared spectroscopy of chemisorbed $\mathrm{NH}_{3} \quad\left(\mathrm{NH}_{3}-\mathrm{IR}\right)$, temperature-programmed desorption of $\mathrm{NH}_{3}\left(\mathrm{NH}_{3}-\mathrm{TPD}\right)$, hydrogen temperature-programmed reduction $\left(\mathrm{H}_{2}-\mathrm{TPR}\right)$, and microreactor testing of the selective catalytic reduction of $\mathrm{NO}$ by $\mathrm{NH}_{3}$. The relationship between surface properties (acidity and reducibility of vanadia species) and SCR activity of supported vanadia species is discussed.

\section{Experimental}

\subsection{Catalyst preparation}

The anatase support (denoted as $\mathrm{TiO}_{2}$ ) with BET surface area of $65.4 \mathrm{~m}^{2} / \mathrm{g}$ was obtained by adding under stirring acetic acid into $n$-butanol solution containing the required amount of $\operatorname{Ti}\left(n-\mathrm{C}_{4} \mathrm{H}_{9} \mathrm{O}\right)_{4}$, followed by adding the appropriate amount of water. The yellow gel formed was aged in air for $12 \mathrm{~h}$, dried at $100{ }^{\circ} \mathrm{C}$ in air for another $24 \mathrm{~h}$, and calcined at $500{ }^{\circ} \mathrm{C}$ in air for $4 \mathrm{~h}$. The $\mathrm{V}_{2} \mathrm{O}_{5} / \mathrm{TiO}_{2}$ catalysts were prepared by impregnating the $\mathrm{TiO}_{2}$ support with a solution containing the required amount of $\mathrm{NH}_{4} \mathrm{VO}_{3}$ dissolved in nitric acid $(14 \mathrm{~mol} / \mathrm{L})$. The mixture was heated at $80{ }^{\circ} \mathrm{C}$ under stirring to remove most of the water and then it was dried at $100{ }^{\circ} \mathrm{C}$ in air for $12 \mathrm{~h}$, calcined at $500{ }^{\circ} \mathrm{C}$ in air for 4 h.

\subsection{Catalytic activity measurement}

The catalytic tests for the SCR of $\mathrm{NO}$ by $\mathrm{NH}_{3}$ were carried out in a glass microreactor with catalyst samples of $0.05 \mathrm{~g}$ and $250-420 \mu \mathrm{m}$ in diameter. Prior to the reaction, the sample was pretreated in flowing air at $500{ }^{\circ} \mathrm{C}$ for $0.5 \mathrm{~h}$. The catalytic reaction was carried out at $300{ }^{\circ} \mathrm{C}$ and 0.1 $\mathrm{MPa}$, with a total flow rate $450 \mathrm{ml} / \mathrm{min}$ (ambient conditions) and GHSV $=7.7 \times 10^{5} \mathrm{~h}^{-1}$ (based on the total bed volume of 
catalyst samples). The inlet concentrations of reactants were $0.075 \% \mathrm{NO}_{x}, 0.08 \% \mathrm{NH}_{3}, 3 \% \mathrm{O}_{2}$, and $\mathrm{N}_{2}$ was the remainder. The NO concentrations before and after reaction were determined by an $N$-(1-naphtyl)-ethylenediamine dihydrochloride spectrophotometer method (Saltzman method) [16-17].

\subsection{Catalyst characterization}

The BET surface areas were obtained by $\mathrm{N}_{2}$ adsorption using a Micromeritics ASAP 2000 instrument with a computer controlled measurement system. The sample was degassed at $300{ }^{\circ} \mathrm{C}$ to a vacuum below $0.4 \mathrm{~Pa}$ before measurement. XRD patterns of $\mathrm{V}_{2} \mathrm{O}_{5} / \mathrm{TiO}_{2}$ catalysts were obtained with a Philips X'pert pro apparatus employing $\mathrm{Ni}$ filtered $\mathrm{Cu} K_{\alpha}$ radiation. The X-ray tube was operated at 40 $\mathrm{kV}$ and $40 \mathrm{~mA}$. The amount of $\mathrm{V}_{2} \mathrm{O}_{5}$ crystallites was determined by XRD quantitative analysis [18]. The intensity ratios of the $\mathrm{V}_{2} \mathrm{O}_{5}(001)$ to $\mathrm{CeO}_{2}(111)$ planes, $I_{\mathrm{V} 205}(001) /$ $I_{\mathrm{CeO} 2}(111)$, in the $\mathrm{V}_{2} \mathrm{O}_{5} / \mathrm{TiO}_{2}$ catalysts with different $\mathrm{V}_{2} \mathrm{O}_{5}$ loading were measured using crystalline $\mathrm{CeO}_{2}$ as an internal reference to evaluate the dispersion capacity of $\mathrm{V}_{2} \mathrm{O}_{5}$ on $\mathrm{TiO}_{2}$.

$\mathrm{NH}_{3}$-TPD was carried out in a quartz U-tube reactor with a thermal conductivity detector (TCD). The powder catalyst $(0.25 \mathrm{~g})$ was oxidized in flowing air $(20 \mathrm{ml} / \mathrm{min})$ at $500{ }^{\circ} \mathrm{C}$ for $0.5 \mathrm{~h}$ and cooled down to $100{ }^{\circ} \mathrm{C}$. The samples were first saturated with pure $\mathrm{NH}_{3}$ at $100{ }^{\circ} \mathrm{C}$ for $0.5 \mathrm{~h}$, and then purged with flowing $\mathrm{He}(20 \mathrm{ml} / \mathrm{min})$ until the TCD signal was stable. Then, the sample was heated to $600{ }^{\circ} \mathrm{C}$ at 5 ${ }^{\circ} \mathrm{C} / \mathrm{min}$ in flowing He.

$\mathrm{NH}_{3}$-IR adsorbed on the catalysts was performed with a Nicolet 5700 FTIR spectrometer. The samples were pressed to self-supporting pieces with the same catalyst mass and dried in flowing $\mathrm{N}_{2}$ at $300{ }^{\circ} \mathrm{C}$ for $0.5 \mathrm{~h}$. Then a sample was saturated with $\mathrm{NH}_{3}$ at $100{ }^{\circ} \mathrm{C}$ for $0.5 \mathrm{~h}$. After purging with $\mathrm{N}_{2}$ at $100{ }^{\circ} \mathrm{C}$ for $1 \mathrm{~h}$, the sample was heated to $400{ }^{\circ} \mathrm{C}$ in flowing $\mathrm{N}_{2}$ at a rate of $10{ }^{\circ} \mathrm{C} / \mathrm{min}$ and the $\mathrm{NH}_{3}$-IR spectra were recorded at different temperatures.

$\mathrm{H}_{2}$-TPR was carried out in a quartz U-tube reactor and $0.10 \mathrm{~g}$ sample was used. The $5 \% \mathrm{H}_{2}-95 \% \mathrm{Ar}$ mixture was switched on at a flowing rate of $20 \mathrm{ml} / \mathrm{min}$ and the temperature was increased linearly at a rate of $10{ }^{\circ} \mathrm{C} / \mathrm{min}$. The consumption of $\mathrm{H}_{2}$ was detected by TCD. $\mathrm{CuO}$ powder was used as reference for the quantitative analysis.

\section{Results and discussion}

\subsection{Catalyst structure}

Table 1 shows the composition, BET surface area, $\mathrm{VO}_{x}$ coverage, and SCR activity of the supported $\mathrm{V}_{2} \mathrm{O}_{5} / \mathrm{TiO}_{2}$ catalysts. The calculation of $\mathrm{VO}_{x}$ coverage for each sample
Table 1 Composition, BET surface area, $\mathrm{VO}_{x}$ coverage, and SCR activity of the supported $\mathrm{V}_{2} \mathrm{O}_{5} / \mathrm{TiO}_{2}$ catalysts

\begin{tabular}{lcccc}
\hline $\begin{array}{l}\mathrm{V}_{2} \mathrm{O}_{5} \text { load- } \\
\text { ing }(\mathrm{wt} \%)\end{array}$ & $\begin{array}{c}A_{\mathrm{BET}} / \\
\left(\mathrm{m}^{2} / \mathrm{g}\right)\end{array}$ & $\begin{array}{c}\mathrm{VO}_{x} \text { coverage } \\
\left(\mathrm{mmol} \mathrm{V} / 100 \mathrm{~m}^{2} \mathrm{TiO}_{2}\right)\end{array}$ & $\begin{array}{c}\text { NO conversion } \\
(\mathrm{mol} \%)\end{array}$ & $\begin{array}{c}\mathrm{TOF}^{*} \\
\left(10^{-3} \mathrm{~s}^{-1}\right)\end{array}$ \\
\hline 0.00 & 65.4 & 0.00 & 3.0 & 0.0 \\
1.48 & 56.2 & 0.29 & 13.9 & 3.7 \\
2.29 & 49.9 & 0.50 & 32.3 & 5.2 \\
2.87 & 45.3 & 0.70 & 68.4 & 8.3 \\
3.64 & 51.0 & 0.78 & 65.0 & 5.4 \\
4.29 & 47.3 & 1.00 & 64.0 & 5.0 \\
6.25 & 45.0 & 1.53 & 61.9 & 3.0 \\
\hline
\end{tabular}

*Moles of NO converted per mole of $\mathrm{V}$ per second.

was based on the BET surface area. Plotted in Fig. 1 are the ratios of the XRD peak intensities of the $\mathrm{V}_{2} \mathrm{O}_{5}(001)$ to $\mathrm{CeO}_{2}(111)$ planes versus loading amount of $\mathrm{V}_{2} \mathrm{O}_{5}$, from which the monolayer dispersion capacity of $\mathrm{V}_{2} \mathrm{O}_{5}$ on anatase was determined by extrapolation to be $1.14 \mathrm{mmol} \mathrm{V/100} \mathrm{\textrm {m } ^ { 2 }}$ $\mathrm{TiO}_{2}\left(6.86 \mathrm{VO}_{x} / \mathrm{nm}^{2}\right)$. This was close to the monolayer surface coverage (7-8 $\mathrm{VO}_{x} / \mathrm{nm}^{2}$ ) determined from Raman data $[5,19,20]$. Above this value, the characteristic peaks attributed to $\mathrm{V}_{2} \mathrm{O}_{5}$ crystallites appeared in the XRD profiles (sample with $\mathrm{V}_{2} \mathrm{O}_{5}$ loading of $6.25 \%$ ). The above experimentally measured monolayer dispersion capacity of $\mathrm{V}_{2} \mathrm{O}_{5}$ on anatase $\left(1.14 \mathrm{mmol} \mathrm{V} / 100 \mathrm{~m}^{2} \mathrm{TiO}_{2}\right)$ was almost the same as the concentration of surface vacant sites on the preferentially exposed (001) plane of anatase [21] (1.16 mmol site $/ 100 \mathrm{~m}^{2} \mathrm{TiO}_{2}$ ) estimated by the incorporation model [22-24]. This suggested that the dispersed vanadium cations were actually located on the octahedral vacant sites on the preferentially exposed (001) plane of anatase $\mathrm{TiO}_{2}$, with the accompanying oxygen anions positioned on the top for charge compensation.

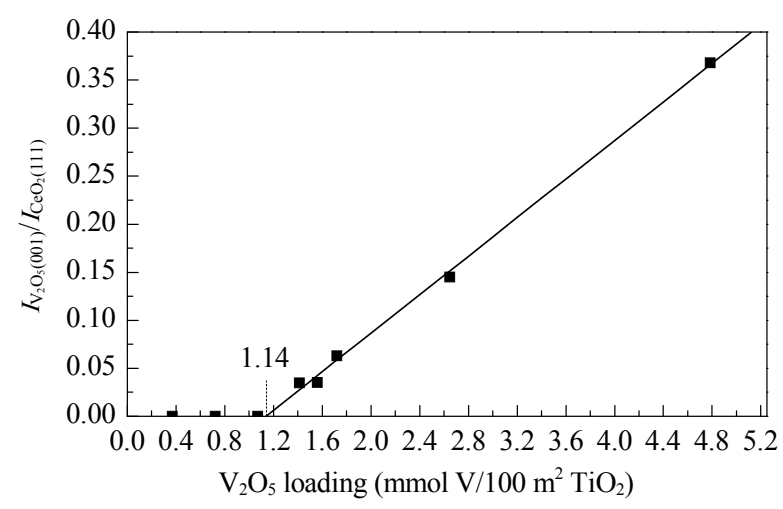

Fig. 1. XRD quantitative analysis of the $\mathrm{V}_{2} \mathrm{O}_{5} / \mathrm{TiO}_{2}$ catalysts.

\subsection{SCR activity}

The NO conversion and NO TOF (expressed in units of moles of $\mathrm{NO}$ converted per mole of $\mathrm{V}$ per second) were measured at $300{ }^{\circ} \mathrm{C}$ under steady state conditions. The results are listed in Table 1 and plotted in Fig. 2. The NO TOF 


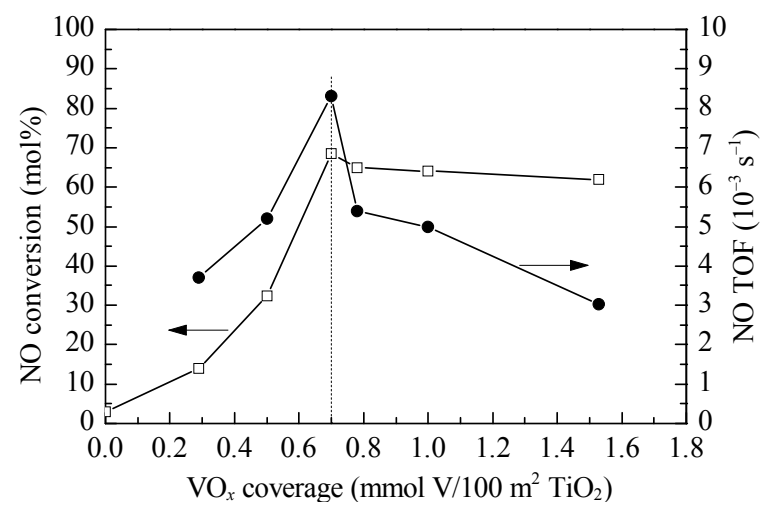

Fig. 2. Effect of $\mathrm{VO}_{x}$ coverage on $\mathrm{NO}$ conversion and $\mathrm{NO}$ TOF for $\mathrm{V}_{2} \mathrm{O}_{5} / \mathrm{TiO}_{2}$ catalysts at $300{ }^{\circ} \mathrm{C}$.

initially increased with $\mathrm{VO}_{x}$ surface coverage and reached a maximum value of $8.3 \times 10^{-3} \mathrm{~s}^{-1}$ at coverage corresponded to slightly more than half a monolayer $\left(2.87 \% \mathrm{~V}_{2} \mathrm{O}_{5}, 0.70\right.$ $\mathrm{mmol} \mathrm{V} / 100 \mathrm{~m}^{2} \mathrm{TiO}_{2}$ ). The TOF then decreased rapidly at higher coverages. The decline of TOF with increase of $\mathrm{VO}_{x}$ coverage from 1.00 to $1.53 \mathrm{mmol} \mathrm{V} / 100 \mathrm{~m}^{2} \mathrm{TiO}_{2}$ can be understood by that the existence of $\mathrm{V}_{2} \mathrm{O}_{5}$ crystallites reduced the ratio of exposed vanadia species on the surface, as indicated by the XRD quantitative analysis results (see Fig. 1) over $\mathrm{VO}_{x}$ monolayer dispersion capacity. Previous studies of the activity of $\mathrm{V}_{2} \mathrm{O}_{5} / \mathrm{TiO}_{2}$ catalysts have also shown an increase in the rate of SCR reaction with $\mathrm{VO}_{x}$ surface coverage in the sub-monolayer region $[7,10]$. This increase has been attributed to a higher specific activity of the polymeric vanadia species [7], and to the accompanying increase of Brönsted acid sites with $\mathrm{VO}_{x}$ surface coverage [10]. The subsequent decrease of TOF at coverages between half and one monolayer has been attributed to the loss of the strong acid sites of the $\mathrm{TiO}_{2}$ support at high $\mathrm{VO}_{x}$ surface coverages [15]. The relationship between the TOF and $\mathrm{VO}_{x}$ surface coverage observed in this work was similar to those given by Amiridis et al. [15], Mutin et al. [25], and Giakoumelou et al. [26]. The reason for the effect of $\mathrm{VO}_{x}$ surface coverage on the SCR activity needs to be further clarified.

\subsection{Surface acidity}

To discuss the effect of $\mathrm{VO}_{x}$ surface coverage in the sub-monolayer region on the SCR activity, the surface acidity should be taken into consideration. Figure 3 shows the $\mathrm{NH}_{3}$-IR spectra of the $\mathrm{V}_{2} \mathrm{O}_{5} / \mathrm{TiO}_{2}$ catalyst with $0.70 \mathrm{mmol}$ $\mathrm{V} / 100 \mathrm{~m}^{2} \mathrm{TiO}_{2}$ and the maximum NO TOF (see Fig. 2). There were four absorption bands. The absorption bands at 1430 and $1680 \mathrm{~cm}^{-1}$ can be assigned to the $\mathrm{N}-\mathrm{H}$ bending vibration of $\mathrm{NH}_{3}$ chemisorbed on Brönsted acid sites (V-OH), while the bands at 1200 and $1552 \mathrm{~cm}^{-1}$ can be assigned to the $\mathrm{N}-\mathrm{H}$ vibration of $\mathrm{NH}_{3}$ chemisorbed on

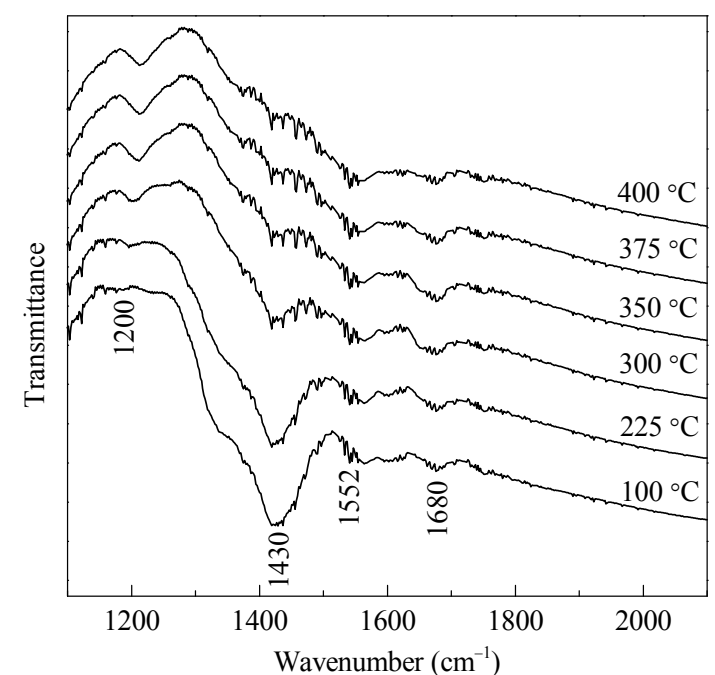

Fig. 3. FT-IR spectra of $\mathrm{NH}_{3}$ adsorbed on $\mathrm{V}_{2} \mathrm{O}_{5} / \mathrm{TiO}_{2}$ catalyst with $0.70 \mathrm{mmol} \mathrm{V} / 100 \mathrm{~m}^{2} \mathrm{TiO}_{2}$.

Lewis acid sites $(\mathrm{V}=\mathrm{O})[10,27,28]$. These data indicated that the dispersed vanadia species in the sub-monolayer region have both Brönsted and Lewis acid sites. With increasing desorption temperature from 100 to $375^{\circ} \mathrm{C}$, the band intensities of the Brönsted acid sites decreased, while those of the Lewis acid sites only changed slightly, suggesting that the Brönsted acid sites of dispersed vanadia species have weaker acidic strength than the Lewis acid sites.

Figure 4 presents the $\mathrm{NH}_{3}$-TPD profiles of the $\mathrm{V}_{2} \mathrm{O}_{5} / \mathrm{TiO}_{2}$ catalyst with different $\mathrm{VO}_{x}$ coverages. Only a broad peak around $270{ }^{\circ} \mathrm{C}$ was observed in the profile of the anatase $\mathrm{TiO}_{2}$ support (Fig. 4(1)). For the supported $\mathrm{V}_{2} \mathrm{O}_{5} / \mathrm{TiO}_{2}$ catalysts, the desorption peak shifted to $180^{\circ} \mathrm{C}$ and a new desorption peak appeared at $450{ }^{\circ} \mathrm{C}$ (Fig. 4(2)). This indicated

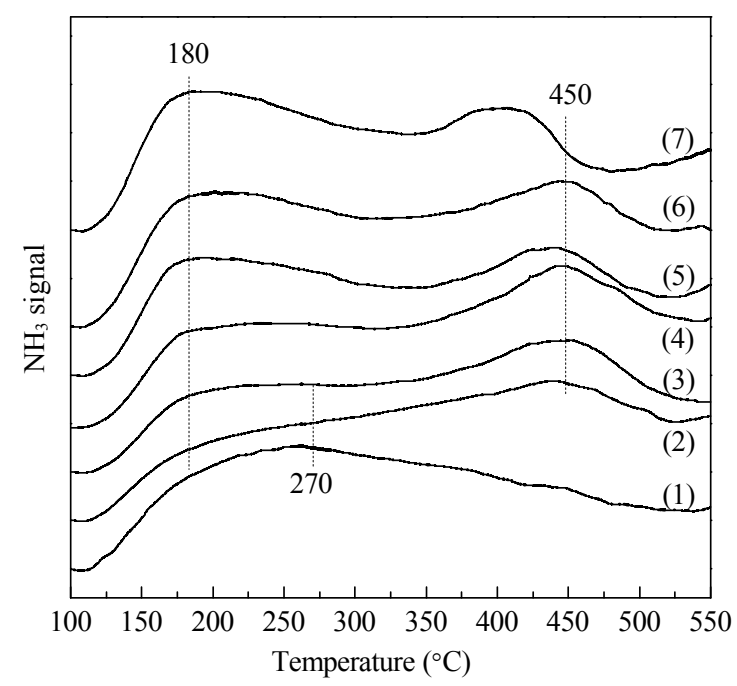

Fig. 4. $\mathrm{NH}_{3}$-TPD profiles of $\mathrm{V}_{2} \mathrm{O}_{5} / \mathrm{TiO}_{2}$ catalysts with different $\mathrm{VO}_{x}$ coverages. (1) $\mathrm{TiO}_{2} ;(2-7) \mathrm{V}_{2} \mathrm{O}_{5} / \mathrm{TiO}_{2}$ catalysts (mmol V/100 m $\mathrm{TiO}_{2}$ ): (2) 0.29 ; (3) 0.54 ; (4) 0.70 ; (5) 0.78 ; (6) 1.00 ; (7) 1.53 . 
that the dispersed vanadia species have two kinds of acid sites, weak and strong acid sites. Combining these results with the $\mathrm{NH}_{3}$-IR results, one can conclude that the Brönsted acid sites of dispersed vanadia species were the weak acid sites, while the Lewis acid sites of dispersed vanadia species were the strong acid sites.

The $\mathrm{NH}_{3}$-TPD peak areas of the $\mathrm{V}_{2} \mathrm{O}_{5} / \mathrm{TiO}_{2}$ catalysts with different $\mathrm{VO}_{x}$ coverages were integrated after peak fitting and deconvolution. As discussed above, the dispersion capacity of vanadium oxide on anatase (complete monolayer) was $1.14 \mathrm{mmol} \mathrm{V} / 100 \mathrm{~m}^{2} \mathrm{TiO}_{2}$ (see Fig. 1). For the $\mathrm{V}_{2} \mathrm{O}_{5} / \mathrm{TiO}_{2}$ catalysts with different $\mathrm{VO}_{x}$ coverages, the contribution of the bare anatase $\mathrm{TiO}_{2}$ support to the $\mathrm{NH}_{3}$-TPD peak area of the catalysts was estimated to give the $\mathrm{VO}_{x}$ coverages based on the $\mathrm{NH}_{3}$-TPD peak areas as

$$
A_{\text {bare } \mathrm{TiO}_{2} \text { contribution }}=\left(1-\frac{C_{\mathrm{V}}}{C_{\mathrm{Vm}}}\right) \times A_{\mathrm{TiO}_{2}}
$$

where $A_{\mathrm{TiO}_{2}}$ was the $\mathrm{NH}_{3}$-TPD peak area contributed by the pure $\mathrm{TiO}_{2}$ support, $C_{\mathrm{V}}$ was the $\mathrm{VO}_{x}$ coverage volume (mmol V/100 $\mathrm{m}^{2} \mathrm{TiO}_{2}$ ), and $C_{\mathrm{Vm}}$ was the monolayer dispersion capacity of vanadium oxide on anatase $(1.14 \mathrm{mmol}$ $\mathrm{V} / 100 \mathrm{~m}^{2} \mathrm{TiO}_{2}$ ). The results are shown in Table 2 and Fig. 5. It can be seen that while the acid amount contributed by the support $\mathrm{TiO}_{2}$ decreased (Fig. 5(2)) and the relative acid amount of strong acid sites also decreased slightly (Fig. $5(3)$ ), the acid amount of weak acid sites increased gradually with increasing $\mathrm{VO}_{x}$ coverage (Fig. 5(4)). This trend was similar to the increase of the total amount of acid sites of the $\mathrm{V}_{2} \mathrm{O}_{5} / \mathrm{TiO}_{2}$ catalysts (Fig. 5(1)), indicating that the increase of the total amount of acid sites was due to the increase in the weak acid sites of the vanadia species.

By subtracting the contribution of the bare anatase $\mathrm{TiO}_{2}$ support to the $\mathrm{NH}_{3}$-TPD peak area, the $\mathrm{NH}_{3}$-TPD peak area due to dispersed vanadia species can be calculated by the formula below, which gives the amount of acid sites due to vanadia species. The result is shown in Fig. 5(5).

$$
A_{\text {vanadium oxide contribution }}=\frac{A_{\mathrm{V}_{2} \mathrm{O}_{5} / \mathrm{TiO}_{2}}-\left(1-\frac{C_{\mathrm{V}}}{\mathrm{C}_{\mathrm{Vm}}}\right) \times A_{\mathrm{TiO}_{2}}}{n_{\mathrm{V}}}
$$

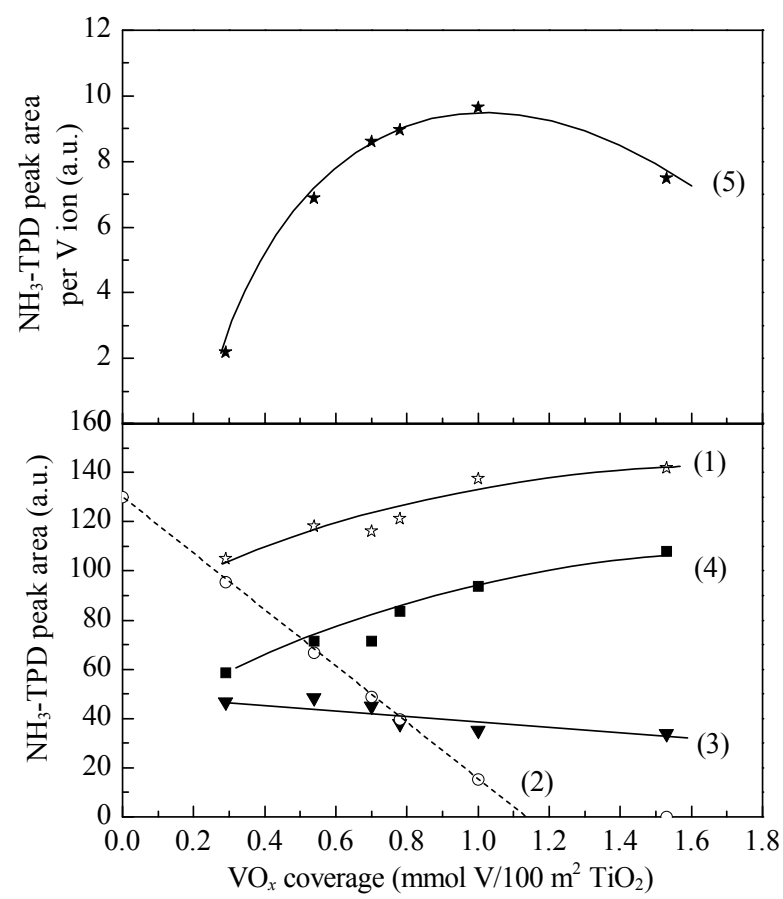

Fig. 5. Effect of $\mathrm{VO}_{x}$ coverage on the $\mathrm{NH}_{3}$-TPD peak area of the $\mathrm{V}_{2} \mathrm{O}_{5} / \mathrm{TiO}_{2}$ catalysts. (1) Total $\mathrm{NH}_{3}$ desorption peak area; (2) Contribution from $\mathrm{TiO}_{2}$; (3) Strong acid site; (4) Weak acid site; (5) Average $\mathrm{NH}_{3}$ desorption peak area per $\mathrm{V}$ ion of the vanadia species.

where $A_{\mathrm{TiO}_{2}}$ was the $\mathrm{NH}_{3}$-TPD peak area due to the pure $\mathrm{TiO}_{2}$ support, $A_{\mathrm{V}_{2} \mathrm{O}_{5} / \mathrm{TiO}_{2}}$ was the $\mathrm{NH}_{3}$-TPD peak area due to the $\mathrm{V}_{2} \mathrm{O}_{5} / \mathrm{TiO}_{2}$ catalyst, and $n_{\mathrm{V}}$ was the number of vanadium ions of the $\mathrm{V}_{2} \mathrm{O}_{5} / \mathrm{TiO}_{2}$ catalyst. It can be seen from Fig. 5 (5) that the relative amount of acid sites contributed by each vanadium ion increased with $\mathrm{VO}_{x}$ coverage in sub-monolayer region. This means that the relative amount of weak acid sites associated with each vanadium ion also increased with increasing $\mathrm{VO}_{x}$ coverage in the sub-monolayer region. As suggested by Topsöe et al. $[10,29]$, the surface Brönsted acid sites of the $\mathrm{V}_{2} \mathrm{O}_{5} / \mathrm{TiO}_{2}$ catalysts are the active sites for the $\mathrm{SCR}$ reaction. In our cases, the increase of NO TOF below a $\mathrm{VO}_{x}$ coverage of $0.70 \mathrm{mmol} \mathrm{V} / 100 \mathrm{~m}^{2} \mathrm{TiO}_{2}$ was correlated with the increase

\begin{tabular}{|c|c|c|c|c|c|c|c|}
\hline \multirow{3}{*}{$\begin{array}{l}\mathrm{V}_{2} \mathrm{O}_{5} \text { loading } \\
\quad(\mathrm{wt} \%)\end{array}$} & \multirow{3}{*}{ 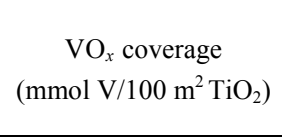 } & \multicolumn{6}{|c|}{$\mathrm{NH}_{3}$-TPD peak area (a.u.) } \\
\hline & & \multicolumn{3}{|c|}{ Acid amount } & \multicolumn{3}{|c|}{ Contributed by } \\
\hline & & Weak & Strong & Total & $\mathrm{TiO}_{2}$ & Vanadia & Each $\mathrm{V}$ ion of vanadia $\left(10^{5} / \mathrm{mol}_{\mathrm{V}}\right)$ \\
\hline 0.00 & 0.00 & - & - & - & 130 & - & - \\
\hline 1.48 & 0.29 & 58.5 & 45.9 & 104.4 & 95.5 & 8.9 & 2.19 \\
\hline 2.29 & 0.50 & 71.4 & 40.7 & 112.1 & 66.8 & 45.3 & 6.87 \\
\hline 2.87 & 0.70 & 71.4 & 45.1 & 116.5 & 48.7 & 67.8 & 8.59 \\
\hline 3.64 & 0.78 & 83.5 & 45.7 & 129.2 & 39.6 & 89.6 & 8.96 \\
\hline 4.29 & 1.00 & 93.7 & 35.3 & 129.0 & 15.3 & 113.7 & 9.64 \\
\hline 6.25 & 1.53 & 107.9 & 33.8 & 141.7 & 0 & 141.7 & 7.48 \\
\hline
\end{tabular}

Table $2 \mathrm{NH}_{3}$-TPD peak areas of $\mathrm{V}_{2} \mathrm{O}_{5} / \mathrm{TiO}_{2}$ catalysts with different $\mathrm{VO}_{x}$ coverages 
of the relative amount of weak acid sites, i.e., Brönsted acid sites of the vanadium ions.

It can also be seen from the $\mathrm{NH}_{3}$-TPD results that the relative amount of the surface acid sites due to the vanadium ions increased from $0.70 \mathrm{mmol} \mathrm{V} / 100 \mathrm{~m}^{2} \mathrm{TiO}_{2}$ and to one monolayer of $\mathrm{VO}_{x}$. This cannot explain the subsequent decline of NO TOF beyond half monolayer of $\mathrm{VO}_{x}$. Some other factor of the $\mathrm{V}_{2} \mathrm{O}_{5} / \mathrm{TiO}_{2}$ catalyst at higher $\mathrm{V}_{2} \mathrm{O}_{5}$ loading and its effect on the NO-TOF activity should be taken into consideration. The $\mathrm{NH}_{3}$-TPD results also showed that the relative amount of surface acid sites contributed by each vanadium ion decreased beyond one monolayer. This was because the existence of $\mathrm{V}_{2} \mathrm{O}_{5}$ crystallites reduced the ratio of exposed vanadia species on the surface.

\subsection{Reducibility of the $\mathrm{V}_{2} \mathrm{O}_{5} / \mathrm{TiO}_{2}$ catalysts}

It has been established that the oxidative dehydrogenation of adsorbed ammonia species by vanadia species is a key step in the SCR of $\mathrm{NO}$ by $\mathrm{NH}_{3}[27,30-32]$. To investigate the reducibility of vanadium ions with different $\mathrm{VO}_{x}$ coverages in the sub-monolayer region, the $\mathrm{H}_{2}$-TPR results of a series of samples are shown in Fig. 6. More information can be obtained from the $\mathrm{H}_{2}$ consumption of each vanadium ion shown in Fig. 7. As shown in Fig. 6(1), pure $\mathrm{TiO}_{2}$ has a small reduction peak at $660{ }^{\circ} \mathrm{C}$, corresponding to the reduction of $\mathrm{Ti}^{4+} \rightarrow \mathrm{Ti}^{3+}$. In contrast, profile of pure $\mathrm{V}_{2} \mathrm{O}_{5}$ (Fig. 6(2)) has three reduction peaks located at 700,726 , and $808{ }^{\circ} \mathrm{C}$, corresponding to the following stepwise reduction of the vanadium oxide [33]: $\mathrm{V}_{2} \mathrm{O}_{5} \rightarrow \mathrm{V}_{6} \mathrm{O}_{13} \rightarrow \mathrm{VO}_{2} \rightarrow \mathrm{V}_{2} \mathrm{O}_{3}$. In comparison with pure $\mathrm{V}_{2} \mathrm{O}_{5}$,

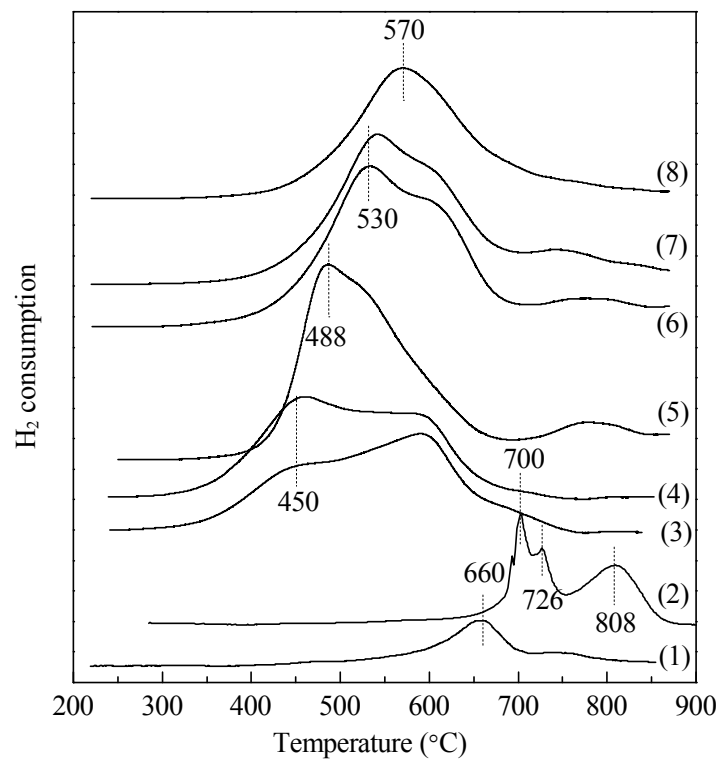

Fig. 6. $\mathrm{H}_{2}$-TPR profiles of $\mathrm{V}_{2} \mathrm{O}_{5} / \mathrm{TiO}_{2}$ catalysts with different $\mathrm{VO}_{x}$ coverage. (1) $\mathrm{TiO}_{2} ;(2) \mathrm{V}_{2} \mathrm{O}_{5} ;(3-8) \mathrm{V}_{2} \mathrm{O}_{5} / \mathrm{TiO}_{2}$ catalysts (mmol V/100 $\mathrm{m}^{2} \mathrm{TiO}_{2}$ ): (3) 0.29 ; (4) 0.54 ; (5) 0.70 ; (6) 1.00 ; (7) 1.43 ; (8) 2.37.

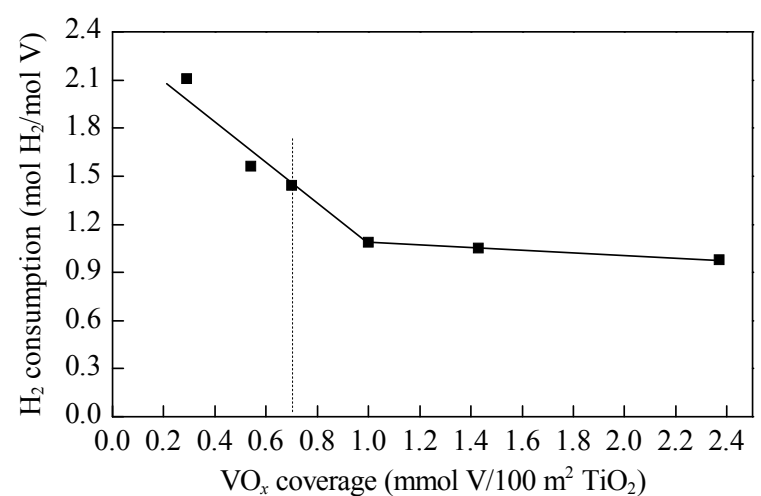

Fig. 7. Effect of $\mathrm{VO}_{x}$ coverage on the average $\mathrm{H}_{2}$ consumption per vanadium ion.

the main feature of the TPR profiles of the $\mathrm{V}_{2} \mathrm{O}_{5} / \mathrm{TiO}_{2}$ samples was the clear shift of their reduction peaks to lower temperatures, as shown in Fig. 6(3). This revealed that the interaction between $\mathrm{V}$ ions and $\mathrm{Ti}$ ions have changed the process of the reduction of $\mathrm{V}$ ions, and supported vanadia species on anatase were easier to reduce. However, the reduction peaks (Fig. 6(3)-(8)) shifted gradually to higher temperature and the $\mathrm{H}_{2}$ consumption of each vanadium ion (Fig. 7) decreased rapidly with the increase of $\mathrm{VO}_{x}$ coverage. These results implied that the vanadium ion reducibility of the $\mathrm{V}_{2} \mathrm{O}_{5} / \mathrm{TiO}_{2}$ catalysts decreased with the increase of $\mathrm{VO}_{x}$ coverage beyond the $\mathrm{VO}_{x}$ coverage of 0.70

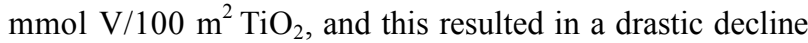
of NO TOF with increased $\mathrm{VO}_{x}$ coverage. This may be the reason for the subsequent decline of NO TOF at coverage between half and one monolayer, even when the relative amount of weak acid sites contributed by each vanadium ion increased.

\subsection{Discussion}

The existence of isolated vanadia species, polymeric vanadia species, and $\mathrm{V}_{2} \mathrm{O}_{5}$ crystallites on $\mathrm{V}_{2} \mathrm{O}_{5} / \mathrm{TiO}_{2}$ catalysts has been shown in the literature [2-7,9,12,20,26,34-36]. Our work suggested that the isolated vanadia species located on the octahedral vacant sites on the surface of anatase $\mathrm{TiO}_{2}$ were the dominant species at $\mathrm{VO}_{x}$ coverages far below the monolayer, and there was an interaction through bridging $\mathrm{V}-\mathrm{O}-\mathrm{Ti}$ bonds between vanadia species and anatase $\mathrm{TiO}_{2}$ (see Scheme 1(A)). As the $\mathrm{VO}_{x}$ coverage increased, isolated vanadia species tend to get dispersed on adjacent octahedral vacant sites, and interacted with their nearest neighbors (either isolated or polymeric vanadia species) through bridging $\mathrm{V}-\mathrm{O}-\mathrm{V}$ bonds to form polymeric vanadia species at the expenses of $\mathrm{V}-\mathrm{O}-\mathrm{Ti}$ bonds below the $\mathrm{VO}_{x}$ monolayer coverage, even if there were still some vacant sites not occupied on the $\mathrm{TiO}_{2}$ surface at this time. This 


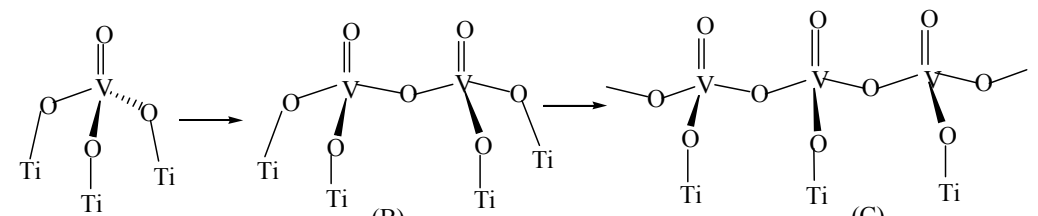

(A)

(B)

(C)

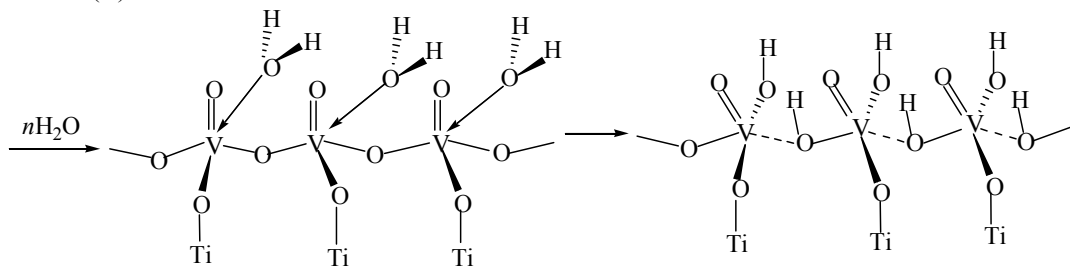

Scheme 1. Proposed structure for isolated (A), dimeric (B), and polymeric (C) of vanadyl species and schemes of the generation of the Brönsted acid sites for polymeric vanadia species on the surface of anatase $\mathrm{TiO}_{2}$.

resulted in an increase of the ratio of $\mathrm{V}-\mathrm{O}-\mathrm{V}$ bonds and a decrease of the ratio of $\mathrm{V}-\mathrm{O}-\mathrm{Ti}$ bonds of the vanadia species (shown in Scheme 1(B) and (C)). According to Miyata et al. [37], the Lewis acid sites can be converted to Brönsted sites upon the introduction of water. The model of the generation of Brönsted acid sites from surface vanadia species suggested by Busca et al. [30] showed that two Brönsted acid site structures of $-\mathrm{OH}$ and $-\mathrm{O}(\mathrm{H})$ - exist on surface vanadyl centers. Thus from our experimental results, we supposed that there was also a Brönsted acid site on bridging $\mathrm{V}-\mathrm{O}(\mathrm{H})-\mathrm{V}$ besides the terminal $\mathrm{V}-\mathrm{OH}$ on the polymeric vanadia species (shown in Scheme 1).

As discussed above, in our work, the vanadium ion reducibility decreased with increased $\mathrm{VO}_{x}$ coverage, and the increase of NO TOF was correlated to the increase of the relative Brönsted acid sites per vanadium ion. By combining these with previous results that the bridging $\mathrm{V}-\mathrm{O}-\mathrm{V}$ sites are active sites for the SCR reaction [3,7,25-26,38-39], it can be suggested that the Brönsted acid sites on bridging $\mathrm{V}-\mathrm{O}(\mathrm{H})-\mathrm{V}$ were also active sites in the SCR reaction, in addition to the terminal $\mathrm{V}-\mathrm{OH}$ of polymeric vanadia species. The increase of the ratio of $\mathrm{V}-\mathrm{O}-\mathrm{V}$ bonds led to the increase of the relative amount of weak acid sites (Brönsted acid sites per vanadium ion) with increasing $\mathrm{VO}_{x}$ coverage, which resulted in the sharp increase of NO TOF below a $\mathrm{VO}_{x}$ coverage of $0.70 \mathrm{mmol} \mathrm{V} / 100 \mathrm{~m}^{2} \mathrm{TiO}_{2}$. As the $\mathrm{VO}_{x}$ coverage increased further, the decrease of the ratio of $\mathrm{V}-\mathrm{O}-\mathrm{Ti}$ bonds of the vanadia species implied that the interaction between $\mathrm{V}_{2} \mathrm{O}_{5}$ and $\mathrm{TiO}_{2}$ becomes weaker and led to the decrease of vanadium ion reducibility of the vanadia species. This resulted in a drastic decline of NO TOF between half and one monolayer of $\mathrm{VO}_{x}$ coverage, although the relative amount of weak acid sites still increased. The decline of NO TOF beyond the monolayer can be understood by that the existence of $\mathrm{V}_{2} \mathrm{O}_{5}$ crystallites reduced the ratio of exposed vanadia species on the surface and reduced vanadium ion reducibility, which was caused by that it was then more difficult for vanadia species to interact with the $\mathrm{TiO}_{2}$ support. Thus, it can be concluded that the acid properties of dispersed vanadia species are the key factors controlling the SCR activity of $\mathrm{V}_{2} \mathrm{O}_{5} / \mathrm{TiO}_{2}$ catalysts at low $\mathrm{VO}_{x}$ coverage, while the reducibility of dispersed vanadia species play a role at high $\mathrm{VO}_{x}$ coverages.

\section{Conclusions}

On $\mathrm{V}_{2} \mathrm{O}_{5} / \mathrm{TiO}_{2}$ catalysts, the NO TOF of SCR at $300{ }^{\circ} \mathrm{C}$ initially increased with increasing $\mathrm{VO}_{x}$ coverage, reached a maximum $\left(8.3 \times 10^{-3} \mathrm{~s}^{-1}\right.$ at a coverage corresponding to slightly higher than half a monolayer $\left(0.70 \mathrm{mmol} \mathrm{V} / 100 \mathrm{~m}^{2}\right.$ $\mathrm{TiO}_{2}$ ), and then decreased rapidly at higher coverages. For $\mathrm{V}_{2} \mathrm{O}_{5}$ dispersed on anatase $\mathrm{TiO}_{2}$, the experimentally measured (from XRD) monolayer dispersion capacity of $\mathrm{V}_{2} \mathrm{O}_{5}$ on

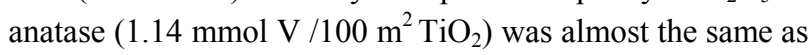
the concentration of surface octahedral vacant sites of anatase estimated by the incorporation model. Isolated vanadia species were dispersed on adjacent octahedral vacant sites, which then formed polymeric vanadia species through bridging $\mathrm{V}-\mathrm{O}-\mathrm{V}$ bonds at the expense of $\mathrm{V}-\mathrm{O}-\mathrm{Ti}$ bonds. The Brönsted acid sites on bridging $\mathrm{V}-\mathrm{O}(\mathrm{H})-\mathrm{V}$ and the terminal $\mathrm{V}-\mathrm{OH}$ of polymeric vanadia species are active sites in the SCR reaction. With increasing $\mathrm{VO}_{x}$ coverage, the relative amount of weak acid sites (Brönsted acid sites per vanadium ion) of vanadia species increased due to an increase in the ratio of the $\mathrm{V}-\mathrm{O}-\mathrm{V}$ bonds of vanadia species. This led to the sharp increase of NO TOF below $\mathrm{VO}_{x}$ coverage of $0.70 \mathrm{mmol} \mathrm{V} / 100 \mathrm{~m}^{2} \mathrm{TiO}_{2}$. With further increase in the $\mathrm{VO}_{x}$ coverage, the vanadium ion reducibility of the vanadia species decreased due to a decrease of the ratio of $\mathrm{V}-\mathrm{O}-\mathrm{Ti}$ bonds of the vanadia species, and this resulted in a decline of NO TOF between half and one monolayer of $\mathrm{VO}_{x}$ coverage. The decline of NO TOF beyond a monolayer can be understood by that the existence of $\mathrm{V}_{2} \mathrm{O}_{5}$ crystallites reduced the ratio of exposed vanadia species and reduced 
vanadium ion reducibility because there was less interaction of vanadia species with the $\mathrm{TiO}_{2}$ support. The SCR activity of $\mathrm{V}_{2} \mathrm{O}_{5} / \mathrm{TiO}_{2}$ catalysts was related to the dispersion state, acidity and reducibility of the vanadia species.

\section{References}

1 Forzatti P. Appl Catal A, 2001, 222: 221

2 Bond G C, Tahir S F. Appl Catal, 1991, 71: 1

3 Bañares M A, Wachs I E. J Raman Spectrosc, 2002, 33: 359

4 Grzybowska-Swierkosz B. Appl Catal A, 1997, 157: 263

5 Wachs I E, Weckhuysen B M. Appl Catal A, 1997, 157: 67

6 Went G T, Leu L J, Bell A T. J Catal, 1992, 134: 479

7 Went G T, Leu L J, Rosin R R, Bell A T. J Catal, 1992, 134: 492

8 Baiker A, Handy B, Nickl J, Schraml-Marth M, Wokaun A. Catal Lett, 1992, 14: 89

9 Lietti L, Forzatti P. J Catal, 1994, 147: 241

10 Topsöe N-Y, Topsöe H, Dumesic J A. J Catal, 1995, 151: 226

11 Marshneva V I, Slavinskaya E M, Kalinkina O V, Odegova G V, Moroz E M, Lavrova G V, Salanov A N. J Catal, 1995, 155: 171

12 Alemany L J, Lietti L, Ferlazzo N, Forzatti P, Busca G, Giamello E, Bregani F. J Catal, 1995, 155: 117

13 Wachs I E, Deo G, Weckhuysen B M, Andreini A, Vuurman M A, de Boer M, Amiridis M D. J Catal, 1996, 161: 211

14 Reiche M A, Hug P, Baiker A. J Catal, 2000, 192: 400

15 Amiridis M D, Wachs I E, Deo G, Jehng J M, Kim D S. $J$ Catal, 1996, 161: 247

16 Ni Z M, Chen A M, Fang C P, Wang L G, Yu W H. J Phys Chem Solids, 2009, 70: 632

17 Tang F S, Xu B L, Shi H H, Qiu J H, Fan Y N. Appl Catal B,
2010, 94: 71

18 Xie Y C, Tang Y Q. Adv Catal, 1990, 37: 1

19 Deo G, Wachs I E. J Catal, 1994, 146: 323

20 Wachs I E. Catal Today, 1996, 27: 437

21 Primet M, Pichat P, Mathieu M V. J Phys Chem, 1971, 75 1216

22 Xu B L, Fan Y N, Liu L, Lin M, Chen Y. Sci China, Ser B, 2002, 45: 407

23 Chen Y, Zhang L F. Catal Lett, 1992, 12: 51

24 Dong L, Chen Y. Chin J Inorg Chem, 2000, 16: 250

25 Mutin P H, Popa A F, Vioux A, Delahay G, Coq B. Appl Catal $B, 2006,69: 49$

26 Giakoumelou I, Fountzoula C, Kordulis C, Boghosian S. J Catal, 2006, 239: 1

27 Ramis G, Busca G, Bregani F, Forzatti P. Appl Catal, 1990, 64: 259

28 Ramis G, Yi L, Busca G. Catal Today, 1996, 28: 373

29 Topsöe N-Y. J Catal, 1991, 128: 499

30 Busca G, Lietti L, Ramis G, Berti F. Appl Catal B, 1998, 18: 1

31 Topsöe N-Y, Dumesic J A, Topsöe H. J Catal, 1995, 151: 241.

32 刘清雅, 刘振宇, 李成岳. 催化学报(Liu Q Y, Liu Zh Y, Li Ch Y. Chin J Catal), 2006, 27: 636

33 Bosch H, Kip B J, van Ommen J G, Gellings P J. J Chem Soc, Faraday Trans 1, 1984, 80: 2479

34 Busca G, Centi G, Marchetti L, Trifiro F. Langmuir, 1986, 2 : 568

35 Gheorghe C, Gee B. Chem Mater, 2000, 12: 682

36 Went G T, Oyama S T, Bell A T. J Phys Chem, 1990, 94: 4240

37 Miyata H, Fujii K, Ono T. J Chem Soc, Faraday Trans 1, 1988, 84: 3121

38 Ozkan U S, Cai Y P, Kumthekar M M. Appl Catal A, 1993, 96 365

39 Gasior M, Haber J, Machej T, Czeppe T. J Mol Catal, 1988, 43: 359 